west, either formed of, or deeply covered by heavy limestone drift, supposed to be the débris of materials eroded from their glens by glacial action. However this may be, the large accumulations which remain in this shape can form but a very small portion of the great sheets of limestone and Coal-measures which once overspread and have been denuded off the face of the country, and of which the mountains themselves are only remnants.

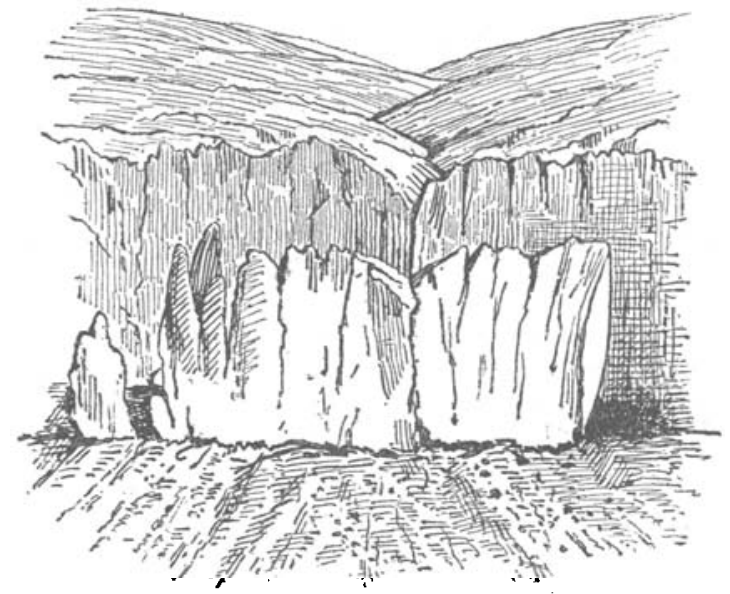

Fro. 2.-Land-slip at the Protestants' Rocks, on the south side of Glen-car, sligo.

The whole aspect of Glen-car forcibly impresses upon an observer the active and powerful agency exerted by atmospheric denudation. It may be plainly seen how the cliffs are gradually receding, yet still preserve their bold character. Naked portions of the mountain tops are covered by small pieces of disintegrating rock; the precipices crumbling away together with rain-washed fragments from above, dress the steep slopes immediately beneath with shingle, the downward motion of which frequently appears to be too rapid for vegetation to cling to; and these shingly slopes are cut through by the small runnels and more rapid mountain torrents.

\title{
V.-ON the Break Betwefen the Upper and Lower Silurian Rocks of the Lake District, as seen between Kirkby Lonsdale and Malham, near Settlr.
}

By T. Me K. Hughes, M.A., F.G.S.

7 HE Rocks included under this head are those already described by Professor Phillips, in his paper "On a Group of Slate Rocks in Yorkshire, between the rivers Lune and Wharfe, etc." (Trans. Geol. Soc., 2nd Series, III. 1). Also by Professor Sedgwick, in his paper " On the Lower Palæozoic Rocks at the base of the Carboniferous Chain, between Ravenstonedale and Ribblesdale" (Quart. Journ. Geol. Soc. VIII. p. 35). 
Professor Sedgwick, in a letter dated 1846, published in Wordsworth's Guide to the Lakes, makes the Coniston Flags the base of the upper group ; but later, in his letter published in 1853 , page 242 , he says that the determination of the fossils by Messrs. Salter and McCoy, and the agreement in mineralogical character of the Coniston Grits with the May Hill Sandstone, led him to draw the line at the base of the grits, and this classification was followed in his synopsis.

Professor Harkness and Mr. Nicholson, in a paper read before the Geological Society in May, 1866, say that the Wenlock and Llandovery Rocks are unrepresented in the Lake Country, and they refer the Coniston Flags and Coniston Grits to the Upper Caradoc.

When that paper was read, I stated to the Society my reason for believing that there had been some mistake in the collection of the fossils from the Coniston Flags, and that the fossils, from the presence of which the flags were referred to the lower group, had not come from the beds containing Cardiola interrupla, and the numerous large Orthoceratites.

In an unpublished letter, written about that date, Mr. Salter said that he felt sure there were two sets of flags, the one belonging to the upper and the other to the lower group; and informs me that he had expressed that opinion on various occasions previously.

The detailed manner in which we are instructed to map the country has enabled me to work out the order of succession of the Silurian rocks along the borders of Yorkshire and Westmoreland, and, I think, to fix the position and nature of the break between the upper and lower group. The result I arrive at is that, "On the evidence, both of mineral structure and of fossils, we are compelled to separate the Coniston Flags from the Coniston Limestone and Calcareous Slates, placing the former at the base of the Upper Silurian series of the Lake district." '

The first Section which accompanies this paper is drawn north-east and south-west along the valley running down from Chapel-le-Dale to Ingleton, and shows the junction of the Green Slates (B.c.), with the Coniston Limestone (B.b.). The beds seen at the north end of the valley are a series of greenish gritty sandstones and slates, which are succeeded by a thick set of coarse grits and conglomerates. Going still south, we cross alternations of greenish slates and tough gritty sandstones for about a mile, when we arrive at the first large quarry, in which a blackish and green slate has been extensively worked. These darker slates are separated from the lighter green and olive slates of the next quarry by alternations of greenish grit and slate.

This appears to be an ascending section all down the valley. The beds dip at an angle of from 70 to 90 in a south-west direction, and the ascending series varies in lithological character so much that there is nothing to suggest that the beds have been anywhere repeated. On the other hand, there are several large gaps where the section is obscured by drift, and where there might be sharp folds or faults. Faults, where the strata are so highly inclined would have to be very large to produce much effect on the measured 

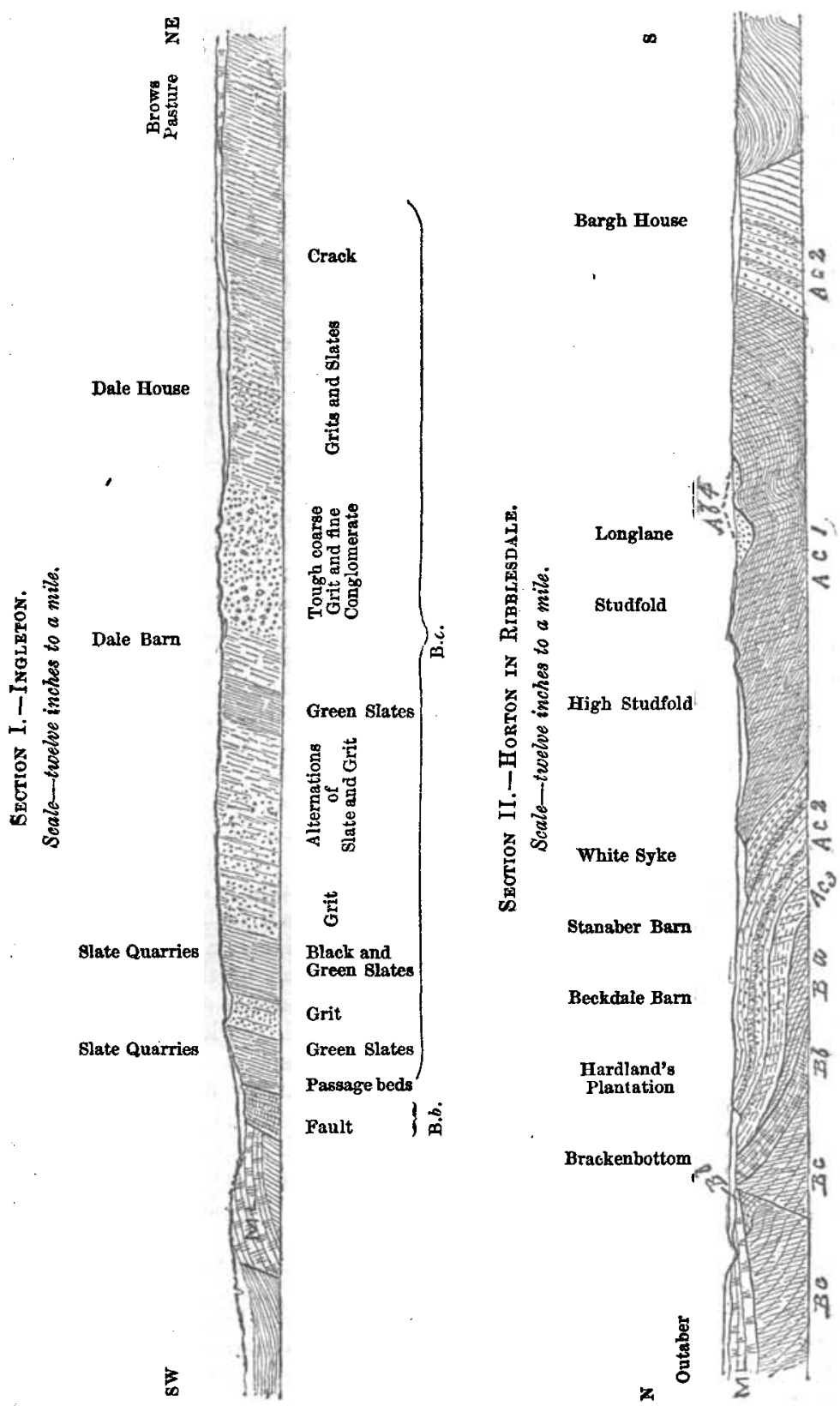
thickness of the beds. Also they must have taken place previous to the deposition of the Carboniferous Rocks, as the great Scar Limestone is seen up both sides of the valley, Iying with an almost horizontal line of junction upon the upturned edges of the Silurian Rocks. If we have here an unbroken ascending series there must be more than 10,000 feet of green slates seen in this valley; but for the reasons above stated the measurement must be received with caution.

These green slates pass up into a thin bedded shivery slate, often breaking up when weathered into small wafer-like fragments. These in turn pass up into more sandy slate, with calcareous bands forming the base of the Coniston Limestone. The limestone has here yielded only some obscure traces of fossils, being considerably altered by its proximity to one of the Great Craven faults. There would appear, therefore, to be a passage from the green slates to the overlying Coniston Limestone, as we find that not only does the dip of the two formations agree exactly, but that there are beds intermediate in lithological character between them. The two formations are seen holding their relative positions in several small sections to the east of those last mentioned; but nowhere else in this neighbourhood is the junction seen.

The next section, No. II., is drawn due north and south, down the east side of Ribblesdale, near Horton. The green slates are seen in the bed of the stream called Douk Gill, which runs out from a " keld" 1 on the east of the village. They dip at a high angle in a southerly direction, and pass up into calcareous slates, full of characteristic Lower Silurian fossils. These are the lower part of the Coniston Limestone, and about 150 yards down the stream they begin to turn up again, so that what we have here of the Coniston Limestone has been preserved in a synclinal, broken at its west end by a fault noticed by Professor Sedgwick (Journ. Geol. Soc., viii. p. 49), which cuts off the Coniston Limestone, bringing the green slates again to the surface. The Lower Silurian rocks are not seen again on this side of the valley, the country. where they might be expected veing entirely obscured by Drift.

Along the road north of Hardland's Plantation, and south-west from that to Hardland's Barn, there is a tough grit, succeeded by flags exposed in the quarry in Hardland's Plantation. These may be seen undulating gently in many places west of Beckdale Barn, and north-west of Redding Barn. They are of no great thickness, and are soon succeeded by more grits, which are seen along the road north-west of Dove Cote, and also sticking out in ice-worn bosses here and there to the south of Stanaber Barn. These grits and flags are the lower grits (A.c.2) with their subordinate flags, which are therefore the equivalent of those west of Crag Hill Barn.

Near Stanaber Barn the grits pass up, through alternations of flags

\footnotetext{
I "Keld" is the term applied to the large springs so common in limestone districts, where the water collected in the pot-holes and crevices of the rock runs out a full stream from a cave below. Prof. Sedgwick informs me that a similar word ("Kelda," I think) is used to denote a similar phenomenon in Iceland.
} 
and roughly cleaved sandstone or grit, into the Coniston Flags (A.c. 1). These flags stand out here and there all over the hill, and are well exposed in large quarries at Studfold.

At the south end of Studfold Low Pasture they pass under more tough grits (A.b. 4), similar in lithological character to those above described (A.c. 2). They are well seen near the guide-post, and elsewhere in Long Lane. The flags turn up again south of the guide-post; but another patch of the grit is preserved in a second small synclinal, and seen in the next stream. These grits (A.b. 4) are the highest beds to be seen in this district. I think they are the same as the grits at the south end of Casterton Fell, where they also have yielded no fossils, and rest on similar flags with Orthoceratites and Graptolites.

I have already described that section in this Magazine, Vol. III. p. 206 ; (a) of that section will be the equivalent of A.c. 1 of this. and $(b)$ of A.b. 4.

On the west side of the valley a similar section can be made out, The green slates (B.c.) are seen in the Ribble, between New Inn and Horton; also near Pettythorn Barn and Beecroft Hall; and consist of the usual alternations of greenish grit, sandstone and slate. The beds are much twisted, and the section obscured by Drift, for the next half mile to the south, where an anticlinal running east southeast and west north-west, brings up the Coniston Limestone near Crag Hill. At Crag Hill the lowest beds consist of sandy or slaty concretionary limestone, with plenty of fossils. The concretions are generally very tough, but sometimes weather into a dark brown earth, showing remains of corals and other fossils. Occasionally this earthy matrix gets washed away, leaving the fossils beautifully preserved. The beds of limestone are thicker and less earthy as we ascend, and at the top we find a bed of a peculiar grey, tough, crystalline limestone. It is exceedingly difficult to see fossils in this, except on the weathered surface. I found only two or three species of Favosites. The junction of this bed and that immediately above it, is nowhere exposed; but it is seen to be succeeded by soft slates (A.c. 3), which pass up into a tough, grey, gritty sandstone. This is probably the base of A.c. 2, and, with one roll, continues with a southerly dip as far as Arco Wood. Near Crag Hill Barn there is a subordinate bed of flags, probably on the same horizon as that in Hardland's Plantation.

A little north of Arco the grits pass under the. Coniston Flags proper, A.c. 1. The Arco Wood quarries are in the lower part of the flags; the Comb's quarry flags are much higher, but they all form one indivisible set. The flags turn up again on the south side of Comb's Quarry, and, with a north north-easterly dip of from $27^{\circ}$ to $75^{\circ}$, form bare ridges, bursting through the soil here and there. The principal of these may be followed east south-east, by Dry Rigg Quarries, across the Ribble, and west north-west, under Moughton Scar, into the next valley, behind the small village called Wharfe. Section III. is drawn due north up this valley, but further west than the flags (A.c. 1) extend. The grits (A.c. 2) also turn up again 
Srotion III.-Crummack.

Scale-12 inches to a mile.

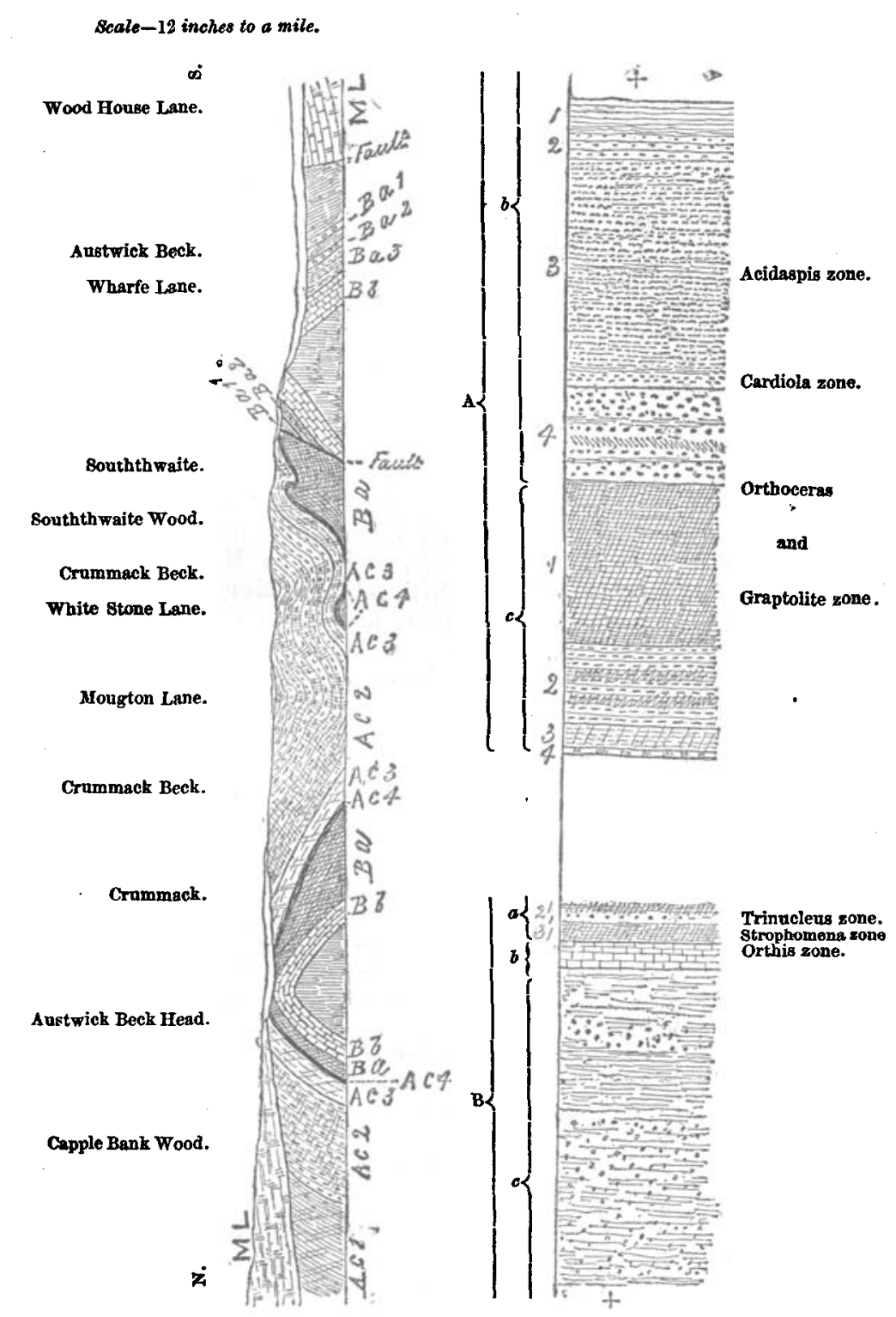

Vertical Section IV. 
from under the flags. The junction crosses the road about half a mile east south-east of Newfield House, and may be followed in a west north-west direction into the next valley, where the boundary line may be traced round to Studrigg Scar; the grits coming up from below the flags on the south, west, and north. South of Swarth Moor the grits are repeated by a fault parallel to the Craven Faults, but older than the Carboniferous rocks under which it passes. Owing to this fault, which is a broken anticlinal with a downthrow on the north, the base of the grits (A.c. 2) is not seen until we get to the Crummack Valley. They are thrown against a lower part of themselves as far as Lower Bark House Barn, on the west of which they come against (B.a.) the slates, grits, and ash-like beds above the Coniston Limestone; then against the Coniston Limestone itself. As this fault has a little more west in it than the strike of the beds on the north side, lower beds abut against it as we proceed westward; and so the base of the grits comes against the fault near the road between Austwick and Wharfe, and can be traced from that point, through Wharfe, across Crummack Beck, south of Souththwaite Wood, across Crummack Lane, near the Limekilns, till it disappears under the Scar of Mountain Limestone. As the grits turn up again on the north, the base line may be traced across the Beck, some way south of Crummack, and up to Moughton Scar; but this line is much obscured by Drift. Under Moughton Scar the slates (A.c. 3) are seen here and there, and lower down one small boss of Coniston Limestone, just enough to prove that it comes there.

Some of the subordinate flags of (A.c. 2) may be seen north of Far End Houses, where we have a bed about 60 feet thick. Some flaggy beds, probably at a lower horizon, occur in the grits north of White Stone Wood, then curving round with the rest of the beds, may be traced to about 100 yards west of Moughton Lane. A still lower set occurs in Souththwaite Wood, and is, probably, about the horizon of the flags of Hardland's Plantation and Crag Hill Barn. In several places along the east edge of the valley, under the limestone cliff, flags occur, alternating with the grit.

The slates (A.c. 3) may be seen rolling about at small angles all down the stream, from the base of the grits in Souththwaite Wood to within 100 yards of Wharfe Mill Dam, where they are cut off by the fault above mentioned.

About fifty yards west of the stream we come to the base of the slates (A.c. 4) which is here a very coarse irregular conglomerate. This may be traced for about a quarter of a mile west-north-west, fragments of the broken ridge occurring along the fields south of Souththwaite. A similar conglomerate is seen at Austwick Beck Head, dipping north-north-east under some slates, and these again under the grits and flags of Capple Bank, which I take to be A.c. 2.

At Austwick Beck Head the conglomerate rests on an irregular cleaved mudstone, of which there is very little seen, and that much weathered.

Below Souththwaite the conglomerate rests on a series of slates, with subordinate more gritty bands (B.a. 2) which pass into rocks 
very like what have sometimes been called ash-beds. Some of these beds cross Crummach Lane just north of Norber Brow. One is seen in the stream close to the Dam House Bridge. The series rolls over, and several such beds are seen dipping to the south, near Jop Ridding, Woodend, Staindale, etc. Below them the slates become more flaggy (B.b. 3); have often long bands of concretions packed parallel to the cleavage, so as to make it very difficult in small sections to make out the bedding. They are well seen on Norber Brow and under the Limestone cliff of Norber, in both of which localities I found several specimens of Trinucleus. These beds pass down into Coniston Limestone, which may be seen near Wharfo Mill Dam, up Wharfe Gill Dyke, etc.

Thus it will be seen that the flags of Horton, in Ribblesdale, lie in a synclinal, the axis of which slopes to the east-south-east; and so in the Crummack valley, we have only the lower part of the flags (A.c. 1) preserved in the hollow of the grits (A.c. 2); while, in the Horton valley, we have the whole of the flags, and at its east end even part of the grits above the flags (A.b. 4), preserved in their then deeper trough.

Two anticlinals, also with their axes sloping to the east-southeast, bring up the lower group (B) on the north and south of this synclinal.

Along the northern anticlinal, the grit A.c. 2 (which is a more marked bed than A.c. 3), is close upon the Coniston Limestone B.b. ; along the southern anticlinal it is separated from the limestone by a very considerable thickness of slates and shales, etc., with Lower Silurian fossils.

Thus A appears to rest upon different beds of the underlying group $B$.

Also the base of $\mathrm{A}$ is sometimes a conglomerate made up of fragments of the older series $B$.

That is to say A rests unconformably upon $B$.

Such are the stratigraphical relations of the rocks in the district under notice. From these data I have constructed a Vertical Section (IV.), to which I shall refer by index letters and numbers, in offering a few remarks upon the lithological character and palæontology.

I have avoided giving names to the subdivisions, as I feel that names derived from locality can probably be more conveniently found in the typical region to the north and west, and that names from characteristic fossils are not likely to hold good over large areas, as all $A$, with which I have chiefly to do, is so undoubtedly one group, that where similar conditions of sea bottom recurred, we must expect to find that the same creatures were there or thereabouts, ready to migrate and re-migrate to suitable areas. Probably, also, most of the divisions will fit in with local names, already used by Professor Sedgwick, such as Ireleth Slates, Brathay Flags, etc.

When the fossils, collected by Mr. Gibbs and myself, have been arranged and determined by Mr. Etheridge, I hope to offer larger and more trustworthy lists.

B.c. Green S'ates.-These are the green slates and porphyry of voL. Iv. - No. Xxxvir. 
Professor Sedgwick. I have dropped the word porphyry, as I have not in this district found any part of them which could be so called. The specimen which I saw in the Kendal Museum also, from further north, seems only a grit, though certainly altered a little. I have not been able to detect any fossils in these beds, unless some obscure black marks which I found in the slates due west of Twisleton Manor House, should turn out to be traces of Fucoids or Graptolites. Professor Harkness has, however, shown that their equivalents further north are of Caradoc age, and the passage from the Coniston limestone into them near Ingleton would seem to bear out this view.

B.b. Coniston Limestone.-A dark blue, close grained, more or less calcareous slate and shale, passing into a hard blue grey crystalline limestone. I have nowhere got the top and bottom of this bed in one section, so I can offer no estimate of its thickness; nor am I prepared to say that it is the very same bed that occurs at the different places from which I have collected fossils, and not rather limestone bands on slightly different horizons of the same series. Fossils are abundant. Speaking generally, the same species occur everywhere, though in some localities they are more numerously represented than in others. Besides the localities referred to in the description of the cross sections, this formation is well exposed and highly fossiliferous in the upper part of Helm Gill, and above Gawthorp near Dent; also in Sarly Beck, north-east of Sedbergh.

The following are some of the fossils :

Halysites catenularia.
Heliolites.
Petraia aquisulcata.
Favosites fibrosa.
F. 2 other sp.
Encrinites.
Cystideans.
A Phyllopod crustacean.
Calymene Blumenbachii (var brevi-
capitata).
Cheirurus bimucronatus.
Cybele verrucosa.
Illenus.
Lichas.
Phacops conophthalmus.
P. sp.
Remopleurides.
Atrypa marginalis.

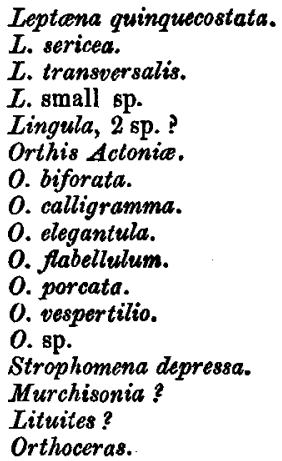

B.a. Strongly cleaved slates. Near Souththwaite the difference between them and the slates (A.c. 3), above may be well examinedthe latter being less altered, and showing the direction of the bedding better. In the upper part the altered grits like Ash-beds (B.a. 2) occur, below which, but some way above the limestone, the Flaggy Slates (B.a. 3) with packed concretions occur. In the upper part of B.a. 3 fragments of Trinucleus become tolerably abundant. So also in coming down Helm Gill we have a geologically ascending section, and in the beds near the bottom, and therefore highest in the series, we find Trinucleus, while fossils are scarce through the beds immediately below. Also in coming south-west from Sarly 
Beck we have an ascending series, and just above the limestone find shales in which Strophomena alternata is the characteristic fossil ; and much higher up, on the south-west side of Rawthay Bridge, shales in which Trinucleus is abundant.

Limestones always form a convenient dividing band, both from their pointing to some physical change, and from their marked lithological character. Therefore, although B.a. passes down into B.b., we may take an arbitrary line for the base of B.a., and we shall find that a change has set in somewhere thereabouts.

In B.a. I have found-

Petraia subduplicata, var. crenulata.

Bncrinites.

Phacops apiculatus?

Phacops, sp. (abtusi-

$\left.\begin{array}{c}\text { caudatus ?) } \\ \text { Trinucleus concentricus. }\end{array}\right\} \begin{gathered}\text { the } \\ \text { upper part. }\end{gathered}$

Orthis biforata.

O. calligramma-large close ribbed var.

o. sp.

- Strophomena depressa. Abundant in $S$. alternata.

S. sp. Orthocoras, ete., etc.

A.c. 4. This bed is seldom exposed. Probaby it does not everywhere exist as a conglomerate, and, moreover, in the other parts of this district which I have had an opportunity of examining, I have never found the upper group near the lower, except where I have plenty of independent evidence of its being brought on by a fault. It is, however, well seen in a few places in the Crummack Valley, where it is a very coarse irregular conglomerate, made up of rolled and angular fragments, which appear to be derived from the grits and fine conglomerates of the green slates; from the Coniston Limestone series-some pieces are very like a bed seen in B.a. close by ; - bits of quartz and slates of various texture, etc. The greatest thickness I could measure was about ten feet. The only fossils I found were Favosites alveolaris? F. fibrosa. It may be that the breccia-like limestone above the Coniston Limestone at Crag Hill is the equivalent of this conglomerate. I have nowhere seen a limestone of that character in the Coniston Limestone, where it has been covered by beds undoubtedly belonging to the lower group B.; also, the only fossils I found in it were the same corals 1 found in the conglomerate; but this is a point to be worked out.

A.c. 3. Slates very uniform in character throughout. Generally a soft mudstone splitting by cleavage and joints into small rhomboidal pieces. Faint lines often indicate the bedding. I have not as yet found any fossils in these beds. The thickness is probably several hundred feet. They pass up through a roughly cleaved sandy slate into-

A.c. 2. Tough grits, or greywacké, with subordinate beds of flags. These have as yet yielded no fossils. They are about one thousand feet thick, and always, in this district, succeed the slates (A.c. 3) with a very uniform character and thickness.

A.c. 1. Flags with subordinate thin beds of grit. These are the

1 The word "greywacké" as defined by Mr. Forbes (p. 229, sup. foot-note) would be a very useful term in this country. We want a name for the tough Silurian rocks which seem to be something between a grit, or sandstone and quartzite.- See Geol. Mag., Vol. III. p. 206, foot-note. 
Coniston Flags proper, in which are the great quarries. Where the bedding and cleavage nearly coincide they form good flags, where the cleavage makes a considerable angle with the bedding they split along the cleavage; but the lines of bedding are well marked across, and the stone breaks into irregular slabs of hardly any value except as "troughs" for walling.

The thickness of these beds is about two thousand feet. Fossils, with the exception of Orthoceratites and Graptolites, are very scarce. I, however found the following; quite enough to connect them with. the beds above, instead of with those below :-

\begin{tabular}{l|l} 
Favosites fibrosa. & Lituites giganteus. \\
Actinocrinus pulcher. & Orthoceras primavum. \\
Graptolites Ludensis. & O. subundulatum. \\
G. sp. & O. sp. (ventricosum ?) \\
Pterinea tenuistriata ? & Worm tracks, etc. \\
Cardiola interrupta. &
\end{tabular}

A.b. 4. Tough grit or greywacké, with a few subordinate flaggy, or slaty beds. These are the highest beds seen in the Horton district. I have estimated their thickness at about twelve hundred feet on Casterton Fell. I have found no fossils in them there, or in the Horton district; but fossils rarely occur in rock of that character. Near Cautley Spout, north-east of Sedbergh, I found a large Lituites in a tough grit, which I must refer to the top of this, or the bottom of the overlying set (A.b.,3). Also, at Helmside, near Dent, there are some flaggy beds, near the top of what I take to be this grit which have yielded the following:-

Cliona.
Spirorbis Lewisii.
Ceratiocaris Murchisoni (See GвoL.
MaG. Vol. III. p. 203).
C. robustus.
Graptolites Ludensis.
G. sp.

Pterinea tenuistriata. Cardiola interrupla.

Oithoceras Ludense.

O. bullatum.

O. angulatum.

0.3 other sp.

A.b. 3. These are the sandy slates of Casterton, Middleton, and Howgill Fells - more than 3000 feet thick. Having already described them in the first mentioned locality, I will now only give a list of fossils, to show that as a group they are the same as those which occur down to the bottom of the Flags.

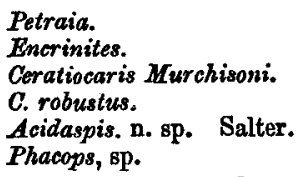

Graptolites.

Pterivea tenuistriata.

Cardiola interrupta.

Lituites.

Orthoceras, 2 sp.

Thus it appears that all (A.) is one series, characterized by such fossils as Cardiola interrupta, that it rests unconformably on a lower series (B.), characterized by such fossils as Orthis Actonice and Trinucleus.

I gather from Prof. Sedgwick, whose kind help on all occasions I take this opportunity of acknowledging, that A.c. 1 to A.c. 4, are what he included under "Coniston Flags," and I would therefore merely wish to return to the classification which he published in 1846, and make the flags so defined the base of the Upper Silurian Series. 